\title{
Elinikäinen oppiminen ja koulutus murroksessa - NERA 2007
}

\begin{abstract}
Onko koulutuksen aikakausi päättynyt, kuten professori Stephen Ball sanoo? Vai onko elinikäinen oppiminen osa universaalia maailmankansalaisuutta, kuten professori Lise Vislie ajattelee - tai onko se keino inmiselle rakentaa omaa ihmisyyttään, sosiaalista pääomaansa ja identiteettiään, kuten professori Tom Schuller näkee? Elinikäisen oppimisen ja koulutuksen murroksesta keskusteltiin 15.-17. maaliskuussa Turun yliopiston kasvatustieteellisessä tiedekunnassa pidetyssä Nordic Educational Research Associationin (NERA) 35. kongressissa.
\end{abstract}

Lo mukaan elinikäisen oppimisen maailma on yksinäisten opiskelijoiden kansoittama, maailma vailla yhteisöllisyyttä ja sitoutumista. Informaatioyhteiskunnan kansalaisuus on osaltaan keinotekoista: sosiaalisia suhteita luodaan yhä useammin verkon välityksellä. Se on johtanut moraalisen vastuun vähenemiseen. Perinteisten traditioiden ja mallien tilalle on noussut itseään jatkuvasti reflektoiva, vaihtelevia identiteettejä omaksuva kansalainen. Olemme muuttuneet samalla entistä vastaanottavaisemmiksi markkinavoimien viesteille. Tieto määritellään nykyään lähinnä markkinoiden hyötynäkökulmasta. Teoreettista ja pohdiskelevaa lähestymistapaa ei pidetä arvossa.

Ball viittaa Lyotardiin mainitessaan tiedon myös kaupallistuneen. On tapahtunut murros modernista postmodernin koulutuksen paradigmaan modernin ajan hyvinvoinnin oppijan tilalle on syntynyt rajaton, joustava, yksinäinen, vastaanottavainen ja vastuullinen, yhteisöllisyyttä vailla oleva oppija. Tämä kehityskulku on johtanut koulutuksen aikakauden päättymiseen.

Professori Lise Vislie Oslon yliopistosta keskittyi koulutukseen liittyvän politiikan ja terminologian murrokseen: esimerkkinään 'elinikäinen koulutus' ja 'elinikäinen oppiminen'. Vallitseva globaali konsensus liittää elinikäisen koulutuksen tulevaisuuden yksilön ja kansallisen talouden ja hyvinvoinnin avaintekijäksi. Koulutus on noussut poliittisesti yhdeksi aikamme tärkeimmistä kysymyksistä. Elinikäinen oppiminen on osa globalisaatiota ja universaalia maailmankansalaisuutta. Kehittyykö elinikäisestä koulutuksesta ylikansallisen politiikan ja käytäntöjen kautta jälkimoderneja yhteiskuntia yhdistävä tekijä vai onko elinikäinen oppiminen mahdollisesti pohjoismaisia hyvinvointivaltiomalleja yhdistävä ideologia? Jääkö elinikäinen oppiminen globaalissa mittakaavassa vain retoriikan tasolle, Vislie aprikoi.

Professori Erno Lehtinen Turun yliopistosta käsitteli informaatioyhteiskunnan haasteita oppimisen näkökulmasta. Yhteiskunta on käynyt läpi äkillisiä ja perusteellisia muutoksia 2000-luvun alun aikana. On syntynyt tieto- ja informaatioyhteiskunta, mikä on tuonut mukanaan tarpeen uudentyyppiselle osaamiselle. Vallitsevan yhteiskunnan nopea muutos tekee ennustamisesta vaikean. Meneillään oleva muutos ja kehitys joka tapauksessa muuttavat oppimisen vaatimuksia, mitkä vaikuttavat jokaiseen kansalaiseen ikään katsomatta. Teknologian nopea kehittyminen ja työkäytäntöjen muuttuminen haastavat koulutuksen perinteisiä tavoitteita. Samanaikaisesti uudet oppimisteoriat ja teknologia tuottavat meille laadullisesti uusia malleja siihen, miten vastata uusiin koulutuksellisiin haasteisiin.

Tieto, pääoma ja mahdollisuus tuottaa informaatiota ovat yksilön sosiaalisen ja taloudellisen hyvinvoinnin edellytykset informaatioyhteiskunnassa. Vaadittavat kvalifikaatiotaidot liittyvät kykyyn ratkaista lisääntyvässä määrin monimutkaiset ongelmat tietotulvan keskellä ja sitoutua tietoyhteiskunnan aktiiviseen, osallistuvaan kansalaisuuteen. Miten koulutusorganisaatiot ja opetus vastaavat käynnissä oleviin muutoksiin, Lehtinen kysyi.

Professori Tom Schuller toimii OECD:n koulu- 
tuksen tutkimus- ja innovaatioyksikön (CERI) johtajana. Hänen mukaan elinikäinen oppiminen voidaan nähdä kehityksenä, minkä avulla ihmiset rakentavat - tietoisesti tai tiedostamattaan - ihmisyyttään, sosiaalista pääomaa tai identiteettiään. Ihmiset hyötyvät koulutusinvestoinneistaan paremman terveyden, vahvempien sosiaalisten verkostojen ja rikkaamman perhe-elämän muodossa. Schullerin mukaan on kuitenkin olemassa perustavanlaatuisia puutteita ja heikkouksia lähestymistavassamme rakentaa ymmärrystä siitä muodosta, minkä elinikäinen oppiminen ottaa, ja sen erilaisten ilmenemismuotojen vaikutuksista. Onko esimerkiksi järkevää tehdä kansainvälisiä vertailuja, ja mitä voimme oppia niistä? Miten voimme ymmärtää paremmin elinikäisen oppimisen seurauksia? Miten kansalliset ja kansainväliset tutkimusyhteisöt voisivat kehittää ymmärrystämme elinikäisestä oppimisesta omissa käytänteissään ja suhteessa muihin, kuten esimerkiksi poliittisiin päätöksentekijöihin?

Professori Sirkka Ahonen Helsingin yliopistosta tarkasteli yhtenäistä peruskoulua historiallisesta viitekehyksestä käsin ja Professori Ingrid Pramling Samuelsson Göteborgin yliopistosta aiheenaan lasten henkilökohtaiset mielenkiinnon kohteet ja harrastuneisuus - integrointi osaksi tavoitteellista perusopetusta. Myös 27 erilaista 'network sessiota' tarjosivat mahdollisuuden osallistua alustuksiin koulutuksen kentän viimeisimmistä tutkimustuloksista ja alkavista tutkimusprojekteista. 'Network sessioiden' aiheet vaihtelivat esimerkiksi varhaiskasvatuksen tutkimuksesta, luokkahuoneiden sisälle ja opettajien työhön sekä koulutuksen filosofiasta sosiologiaan. Myös liikunnan ja terveyden erilaiset teema-alueet olivat kiitettävästi edustettuina. Kolmelle päivälle jakautuneet 'symposiumit' kattoivat kaiken kaikkiaan 21 erilaista teemaa koulutuksen ja oppimisen saralta, mitkä täydensivät 'network sessioiden' antia.

NERA-kongressi ulottautui laajalti Turun yliopiston kampusalueelle. Kasvatustieteiden, yhteiskuntatieteiden ja oikeustieteiden tiedekunnat sekä kemian laitos olivat kongressin käytössä. Neljän tiedekunnan välinen yhteistyö ratkaisi kaiken kaikkiaan 733 osallistujan mukanaan tuomat tilankäyttöön liittyneet haasteet. Varsinaisia pääesitelmiä, eli 'key note - luentoja' oli yhteensä kuusi. Pääluennoitsijat olivat erittäin korkeatasoisia. Vieraat saivat nauttia poikkeuksellisen hyvistä alustuksista liittyen elinikäisen oppimisen kysymyksiin ja haasteisiin pohjoismaissa ja laajemmin Euroopassa. Pääesitelmät ovat luettavissa kongressin verkkosivuilta www.congress. utu.fi/nera07.

\section{Vieraanvarainen isäntäkaupunki}

Kaikki osallistujat eivät mahtuneet pääluentosaliin. Sen vuoksi tiedekunnan liikuntasaliin oli asennettu iso valkokangas, minkä kautta oli myös mahdollista seurata luentoja. Kuvan laatu oli onnistuttu saamaan korkeatasoiseksi, mutta äänentoisto ei pystynyt täysin vastaamaan suuren kuulijakunnan tarpeita. Kongressiosallistujille järjestettiin vastaanotto Turun VPK-talolla ja illallinen tarjottiin tunnelmallisessa ravintola Koulussa. Turun yliopiston kasvatustieteiden laitoksen liikuntatutkijat järjestivät salibandyturnauksen ja vierailla oli mahdollisuus tutustua myös perinteiseen suomalaiseen kulttuuriin, saunaan ja avantouintiin. Vieraat pääsivät halutessaan tutustumaan myös Euroopan vuoden 2011 kulttuurikaupunkiin kiertoajelulla. Kongressin kruunasi lauantain päivällinen Turun linnassa. Turun yliopiston kasvatustieteiden tiedekunnan järjestämä NERA 2007 sai osallistujilta osakseen paljon kiitosta. Vuoden 2008 NERA - kongressi järjestetään maaliskuun 6-8. päivä Tanskan Kööpenhaminassa. Tavataan siellä!

\section{Jani Siirilä \& Sanna Siirilä}

